\title{
JALUR PELAYARAN PERDAGANGAN KUNO DI SELAT BANGKA SEBAGAI LETAK STRATEGIS BERKEMBANGNYA KEKUASAAN MARITIM SRIWIJAYA ABAD VII-VIII MASEHI
}

\author{
Kabib Sholeh, Widya Novita Sari, Lisa Berliani \\ Program Studi Pendidikan Sejarah FKIP Universitas PGRI Palembang \\ Alamat korespondensi: habibsholeh978@gmail.com
}

Diterima: 15 Desember 2018; Direvisi: 18 Januari 2019; Disetujui: 20 Januari 2019

\begin{abstract}
Bangka Island is an archipelago located in the east of Palembang. The Bangka Islands have been known in ancient times as a strategic area on the ancient trade voyage routes of the VII-VIII century AD. The purpose of this study was to analyze the location of the Bangka Strait which is strategically located on the Sriwinaya trade shipping lane. Analyzing the relevance of Srivijaya maritime development towards the Bangka Strait. The method used in this study is the historical (historical) method, with a multi-aproac approach consisting of politicians, economologists and sociologists. The steps are heuristic or source collection, verification of sources, interpretations and historiography. The kingdom of Srivijaya was known as the great kingdom in power at sea. The Bangka Strait is a strategic place in the Sriwijaya trade shipping lane. A strategic place for foreign traders from Arabia, India and China who go through the Bangka Strait route, indirectly these traders will stop by first in the Sriwijaya ports. Srivijaya ruled the Bangka Strait region and played a role in the security of traders passing through the Bangka Strait. With the existing maritime power, the Srivijaya king also mobilized his troops to secure the area. Aside from being a political policy, the Bangka Strait was very important for the expansion of Srivijaya's power.
\end{abstract}

Keywords: Bangka Strait; shipping lane; Sriwijaya trade.

\begin{abstract}
Abstrak
Pulau Bangka merupakan wilayah kepulauan yang terletak di sebelah Timur Palembang. Kepulauan Bangka sudah dikenal pada masa kuno sebagai wilayah yang strategis pada jalur pelayaran perdagangan kuno masa Sriwijaya abad VII-VIII Masehi. Tujuan penelitian ini adalah untuk menganalisis jalur pelayaran perdagangan kuno di selat Bangka, menganalisis relevansi perkembangan maritim Sriwijaya terhadap Selat Bangka. Metode yang digunakan pada penelitian ini adalah metode sejarah (historis), dengan pendekatan multi aproac yang terdiri dari politikologis, ekonomologis dan sosiologis. Adapun langkah-langkahnya adalah heuristic atau pengumpulan sumber, verifikasi sumber, interpretasi dan historiografi. Kerajaan Sriwijaya dikenal sebagai kerajaan besar yang berkuasa di laut. Selat Bangka menjadi tempat yang strategis dalam jalur pelayaran perdagangan masa Sriwijaya. Tempat yang strategis bagi para pedagang asing dari Arab, India dan Cina yang melalui jalur selat Bangka maka secara tidak langsung para pedagang tersebut akan mampir terlebih dahulu di pelabuhan-pelabuhan Sriwijaya. Sriwijaya berkuasa akan wilayah Selat Bangka sekaligus berperan dalam keamanan para pedagang yang melewati Selat Bangka. Dengan kekuatan maritim yang ada, raja Sriwijaya juga mengerahkan para tentaranya untuk mengamankan wilayah tersebut. Selain sebagai kebijakan politik, Selat Bangka sangat penting untuk perluasan kekuasaan Sriwijaya.
\end{abstract}

Kata Kunci: Selat Bangka, jalur pelayaran, perdagangan Sriwijaya.

\section{A. Pendahuluan}

Selat Bangka merupakan pemisah antar Bangka dengan daratan Sumatera, selat Bangka sendiri berada di kepulauan Provinsi Bangka Belitung. Nama Bangka sendiri diambil dari kata vanca (wangka) yang dalam bahasa Sanskerta berarti timah yang juga disebut dalam prasasti Kota Kapur. Letak geografis Selat Bangka sendiri terdapat di sebelah timur Selat Karimata, sebelah selatan terbentang Laut Jawa, sebelah barat pulau Sumatera, sebelah utara terhampar luas Laut Natura yang berhubungan langsung dengan Laut Cina Selatan (Kartiwa, 2009: 5). 
Selat Bangka juga merupakan jalur yang dilewati para pedagang kuno paling ujung dari pintu masuk Selat Malaka menuju ke negeri Cina dan jalur perdagangan yang ramai seperti halnya Selat Malaka. Di tambah pula Selat Bangka yang strategis dengan berhadaphadapan langsung dengan pintu masuk ke arah pedalaman mengikuti aliran muara Sungai Musi menuju Palembang. Kondisi wilayah tersebut memberikan isyarat bahwa letak Selat Bangka pada masa Sriwijaya sangatlah penting karena banyak para pedagang yang berkunjung ke pusat Kerajaan Sriwijaya di Palembang (Sholeh, 2015: 98-99).

Kerajaan Sriwijaya yang terletak di Palembang membuat Sriwijaya sebagai jalur Pelayaran dan perdagangan di Nusantara mulai dari Selat Malaka yang menjadi pintu masuk sampai ke Selat Bangka yang akhirnya masuk di Pusat Kerajaan Sriwijaya yang disebut sebagai jalur-jalur pelayaran dan perdagangan internasional. Bagi Sriwijaya wilayah perairan Pulau Bangka sangat penting untuk dijadikan wilayah kekuasaannya, terbukti pada tahun 686 sesuai tahun dalam prasasti Kota Kapur. Dengan demikian raja Sriwijaya memang benarbenar menginginkan wilayah Bangka terutama daerah peraiaran Bangka untuk dijadikan wilayah kekuasaannya. Sriwijaya melakukan hal tersebut bukan hanya semata-mata ingin menjadi penguasa saja, tetapi melakukan politik perluasan dengan strategi penguasaan wilayah jalur-jalur pelayaran perdagangan yang harus dikendalikan oleh Sriwijaya.

Sebagai jalur pelayaran dan perdagangan internasional, Kerajaan Sriwijaya memiliki kapal-kapal besar dalam mempertahankan kekuasaanya di laut. Dengan menggunakan kapal-kapal tersebut tentara Sriwijaya menguasai dan mengendalikan jalur pelayaran dan perdagangan mulai dari Samudera Hindia, Selat Malaka, Selat Bangka, Selat Sunda, Selat Karimata sampai laut Cina Selatan (Irfan, 1983: 67).

Melihat bukti-bukti sejarah dan pentingnya selat Bangka bagi jalur pelayaran perdagangan kuno, maka Sriwijaya sebagai pemilik hegemoni maritim di laut nusantara serasa memiliki tujuan yang besar bagi perkembangan pelayaran perdagangan pada masa itu. Jalur pelayaran yang strategis mulai dari selat Malaka sampai selat Bangka menjadi jalur utama untuk dikuasai terutama pada selat Bangka.

Dengan demikian pada permasalahan-permasalahan mengenai letak strategis jalur pelayaran perdagangan kuno di selat Bangka dan pengaruhnya terhadap perkembangan kekuasaan Sriwijaya. Maka penulis tertarik untuk membahas lebih dalam lagi tentu dengan berbagai analisis dan sudut pandang yang berbeda berdasarkan bukti-bukti yang ada.

\section{B. Metode Penelitian}

Metode penelitian yang digunakan adalah metode historis, bertujuan untuk membuat rekonstruksi masa lampau, secara sistematis dan objektif dengan cara mengumpulkan, mengevaluasi, dan memverifikasi bukti-bukti guna menegakkan fakta-fakta guna memperoleh kesimpulan yang akurat (Suryana, 2010:18). Penelitian ini juga menggunakan banyak pendekatan dari berbagai bidang keilmuan (Multi Aproach) yaitu pendekatan sosiologis, ekonomologis dan politikologis.

Adapun tahapan-tahapan metode sejarah pada penelitian ini adalah pertama, Heuristik atau pengumpulan sumber. seperti sumber pustaka (library research), jurnal-jurnal, laporan hasil penelitian arkeologi dan buku-buku relevan termasuk dokumen dan arsip. 
Kedua, Verifikasi Sumber, pada tahap ini peneliti melakukan verifikasi sumber atau kritik dengan tujuan mendapatkan data-data yang benar-benar valid dan autentik.

Ketiga, Interpretasi (Penafsiran Sejarah), adalah kegiatan menganalisis data yang sudah dikumpulkan dari berbagai sumber dan sudah dilakukan verifikasi, maka kegiatan ketiga ini penulis melakukan interpretasi atau disebut juga tahap analisis data (penafsiran sejarah). Pada tahap ini peneliti melakukan sintesis atas sejumlah fakta dan data yang diperoleh dari sumber-sumber sejarah tentang kehidupan sosial-budaya masyarakat Sriwijaya dan bersama-sama dengan teori-teori, disusunlah fakta itu ke dalam suatu interpretasi yang menyeluruh. Peneliti akan melakukan perbandingan dengan data tersebut dan melakukan serangkaian secara abstrak untuk membentuk struktur penulisan yang baik.

Keempat, Historiografi (penulisan sejarah), adalah cara penulisan, penyusunan atau pelaporan hasil penelitian sejarah yang telah dilakukan. Dalam historiografi seorang penulis tidak hanya menggunakan keterampilan teknis, penggunaan kutipan-kutipan dan catatan-catatan tetapi penulis juga dituntut menggunakan pikiran kritis dan analisis (Syamsudin, 1996:153). Pada tahapan terakhir dalam penelitian ini, peneliti melakukan penulisan sejarah dengan tujuan hasil yang ditulis dapat memberikan gambaran yang jelas mengenai proses penelitian dari awal sampai akhir.

\section{Pembahasan}

Letak Strategis Selat Bangka dalam Pelayaran Perdagangan Kuno Abad VII - VIII Masehi.

Dalam pelayaran ke Timur laut, semua kapal menuju pelabuhan Sumatera terletak agakselatan Selat Malaka dan tidak melewati jalur dekat Cina yang melintasi sekitar Singapura. Para sejarawan tidak memperhatikan perkembangan perjalanan dari Hindia, melalui Selat Malaka ke Nusantara. Namun, karena hanya pelayaran dari Nusantara ke Cina yang memungkinkan perdagangan di Nusantara (Woltes, 2011: 19). Diduga kuat bahwa Selat Malaka memberikan pintu jalan ke Nusantara dari India dan Selat Bangka ke Cina sehingga Selat Bangka menjadi strategis banyak pelayaran dan perdagangan yang dilakukan orang asing melewati Selat tersebut.

Abad ke-7 Masehi jalur pelayaran dan perdagangan di wilayah perairan nusantara bagian barat yang paling sering dilayari adalah Selat Malaka, Selat Bangka, Selat Gelasa serta Selat Karimata. Pelayar dan pedagang dari Selat Malaka melewati banyak kapalkapal perniagaan melintas di Selat Bangka dalam perjalananya menyinggahi pelabuhan Sriwijaya yang merupakan jalur ramai sejak lalu (Novita, 2013: 47-48). Pulau Bangka selain tempatnya strategis bagi pelayaran dan perdagangan pada masa kuno tetapi Selat Bangka juga dapat dijadikan benteng pertahanan paling utama dan paling terluas apabila dilihat dari arah laut yang berhadapan langsung dengan Sungai di Palembang.

Letak Selat Malaka mengundang perdagangan di daratan Asia Tenggara untuk meluas ke Selatan, suatu hal yang baru terjadi setelah perdagangan dengan India berkembang, penduduk Sumatera khususnya di pantai Timur, 
bukan asing lagi dalam mengenal perdagangan Internasional. Jalur perdagangan yang dikuasai kerajaan Sriwijaya semakin ramai dan penting disebabkan kerajaan Sriwijaya mampu menjaga keamanan, di samping letak geografisnya yang menguntungkan. Selain jalan dagang lewat lautan luas, para pedagang Arab, Cina, Persia dan India. (Sholeh, 2017: 4).

Dalam melewati Selat Malaka kemudian Selat Bangka hal tersebut membuat Selat Bangka menjadi strategis karena banyak pelayar dan pedagang asing melewati Selat itu menjadi suatu Kerajaan Sriwijaya menjadi strategis pula banyak yang mampir untuk berdagang dan banyak juga untuk berlayar dan juga kestrategisan Selat Bangka khususnya kepulauan Bangka Belitung karena terletak di tengahtengah Selat Malaka dan Laut Cina Selatan di bagian Utara serta Laut Jawa di bagian Selatan (Wiyana, 2013: 100).

Jalur pelayaran perdagangan Selat Malaka kuno dimulai masa pada perubahan geografis.Pelayaran jalur perdagangan pantai timur Sumatera masa Sriwijaya sampai sekarang sebenarnya sedikit banyaknya sudah mengalami perubahan terutama mengenai letak geografisnya. Jalur pelayaran perdagangan letak kestrategisan nya yang tidak kalah pentingnya untuk diketahui adalah jalur Selat Bangka. Pulau Bangka merupakan wilayah kepulauan yang terletak sebelah Timur kota Palembang, atau kepualauan paling ujung dari serentetan pulau-pulau dari Semenanjung Malaya, Riau - Lingga, dan menuju Pulau Bangka.

Pulau Bangka sudah dikenal pada masa kuno sebagai kepulauan yang letaknya di wilayah pantai Timur Sumatera yang sekaligus wilayah yang menempati letak strategis bagi pelayaran, karena di Bangka sendiri terdapat sebuah Selat atau laut sempit yang diapit antara daratan Suamatera dengan Pulau Bangka yang disebut Selat Bangka (Sholeh, 2018: 6).Jalur-jalur pelayaran masa Sriwijaya diawali jalur pelayaran prrdagangan Selat Malaka masa kuno dimulai terletak mengenai letak geografisnya.Menurut Obdeyn dalam laporan penelitiannya mengenai peta kuno masa Sriwijaya, deretan pulau-pulau mulai dari wilayah Semenanjung Malaya - kepulauan Riau - Lingga dan sampai Pulau Bangka pada masa itu masih menjadi satu daratan dengan gugusan-gugusan pulau. Sedangkan kondisi yang sekarang deretan gugusan kepulauan tersebut sudah terpisah karena terjadi pencairan es di wilayah kutup Utara sehingga pulau-pulau yang dahulunya menyatu pada saat sekarang menjadi tergenang air dan terpisah-pisah. (sholeh, 2018: 4).

Menurut teori Sukmono, para pedagang harus memutar wilayah Bangka terlebih dahulu karena kondisi secara geografis pulau-pulau atau daratan yang ada di wilayah pantai sebelah Timur Sumatera yang masih dalam kondisi menyatu mulai dari Kepulauan Riau-Lingga sampai ke Bangka. Faktor lain yang membuat Kerajaan Sriwijaya menjadi kekuasaan di laut sehingga disebut kerajaan maritim terbesar pada masa itu adalah faktor kekuatan tentara yang kuat serta manajemen seorang pemimpin yang tegas dan bijaksana dalam mengendalikan jalur-jalur pelayaran perdagangan yang ada di Nusantara (Sholeh, 2015: 50).

Wilayah yang dianggap penting sebagai jalur pelayaran pada masa itu adalah Selat Bangka dan Selat Karimata karena jalur itu dilewati oleh para pedagang yang bertujuan ke Cina dan 
sebaliknya. Maka para pedagang mau tidak mau harus berlayar memutar terlebih dahulu ke Pulau Bangka menuju Utara melewati laut Cina Selatan untuk tujuan ke Asia Timur. Jadi para pedagang yang masuk melewati Selat Malaka pada masa Sriwijaya tidak bisa langsung memutar di Semenanjung Malaya dan langsung ke arah utara menuju Cina, tetapi harus melewati serenteran daratan kepulauan Riau-Lingga sampai Selat Bangka dan memutari Pulau Bangka menuju ke utara. (Kabib, 2015, 90-91).

\section{Selat Bangka terhadapPerkembangan Kekuasaan Maritim Sriwijaya Abad VII-VIII Masehi}

Bagi Sriwijaya wilayah perairan Pulau Bangka sangat penting untuk dijadikan wilayah kekuasaannya, terbukti pada tahun 686 sesuai tahun dalam prasasti Kota Kapur. Dengan demikian raja Sriwijaya memang benarbenar menginginkan wilayah Bangka terutama daerah peraiaran Bangka untuk dijadikan wilayah kekuasaannya. Sriwijaya melakukan hal tersebut bukan hanya semata-mata ingin menjadi penguasa saja, tetapi melakukan politik perluasan dengan strategi penguasaan wilayah jalur-jalur pelayaran perdagangan yang harus dikendalikan oleh Sriwijaya. Dengan memanfaatkan kondisi perairan Selat Bangka yang ramai dan sekaligus ramai pula akan perompak-perompaknya, maka Sriwijaya datang menjadi penguasa wilayah tersebut (Sholeh, 2018: 6-7).

Sriwijaya yang dikenal sebagai penguasa laut atau kerajaan maritimsudah lama mengincar Selat Malaka untuk dijadikan wilayah kekuasaannya. Melihat kondisi yang tidak memungkinkan untuk langsung menaklukan jalur pelayaran Selat Malaka maka Sriwijaya, seperti wilayah
Bangka, perairan Selat Sunda, dam wilayah Jambi. Setelah wilayah jalur pelayaran yang dianggap strategis dapat dikuasai, selanjutnya untuk menguasai Selat Malaka sebagai pintu masuk pedagang melewati jalur pelayaran Nusantara yang seperti di Bangka yaitu Prasasti Kota Kapur. Yang memberikan informasi bahwa penguasa-penguasa wilayah mulai dari Bangka, Lampung, dan Jambi pada abad ke-7 Masehi sudah dikuasainya (Sholeh, 2015: 95). Ditambah pula dalam Selat Bangka menjadi letak strategis yang banyak dilalui kapal-kapal asing dan letak dipesisir laut sehingga diketahui oleh bangsa asing yang membuat Sriwijaya ingin menguasai Bangka seperti dalam ditemukanya Prasati Kota Kapur yang banyak menyebut kata "Sriwijaya".

Menguasai Pulau Bangka, Sriwijaya berangapan selain pentingnya perairan di Pulau Bangka yang harus ditaklukam pertama kali, oleh karena itu Pulau Bangka merupakan wilayah sangat strategis sebagai pintu utama untuk memasuki pusat Kerajaan Sriwijaya dan setidaknya mau tidak mau wilayah di perairan Selat Bangka harus dikuasai dan menjadi daerah kekuasaanya. Dengan pengaruh Sriwijaya di selat, era baru pun dimulai dalam sejarah perdagangan Nusantara zaman dulu (Woltes, 2011: 299).

Dalam penaklukan Sriwijaya melewati Selat Bangka terdapat juga hubungan dengan keduanya di provinsi Bangka yaitu peninggalan Sriwijaya pada prasasti Kota Kapur, yang berangka 686 M. Prasasti ini ditemukan tahun 1892 di lahan yang dikelilingi benteng tanah di tepi Sungai Mendo, desa Kota Kapur. Isi nya berupa ancaman atau kutukan yang biasa disebut prasasti persumpahan menjelaskan bagi siapa saja yang tidak tunduk kepada raja Sriwijaya akan di 
bumi anguskan dan dijelaskan pada Prasasti terdapat kalimat penaklukan "Bumi Jawa" yang artinya penaklukan tersebut dasar keinginan membuka jalur dalam memudahkan masuk menyebrangi wilayah Tanah Jawa untuk mengusai Selat Sunda (Sholeh, 2015: 53).

Lokasi situs Kota Kapur sendiri terletak ditepian jalan laut (Selat Bangka) yang menghubungkan Palembang dan Jawa. Situs Kota Kapur sendiri merupakan situs penting dalam kaitannya dengan Sriwijaya karena ditemukan sebuah persumpahan yang dikeluarkan oleh Sriwijaya dan sebuah sagmen arca batu yang hinduistik. Prasasti Kota Kapur adalah salah satu dari lima buah prasasti kutukan yang dibuat oleh Dapunta Hyang seorang penguasa dari kadatuan Sriwijaya. Prasati ini dipahat pada sebuah batu berbentuk tugu persegi-segi dengan ukuran tinggi $177 \mathrm{~cm}$, lebar $32 \mathrm{~cm}$ pada bagian dasar dan $19 \mathrm{~cm}$ pada bagian puncak. Batu kutukan yang bertulis dalam aksara Pallawa dan berbahasa Melayu Kuno ini ditemukan bulan Desember 1892 oleh J.K Van Der Meulen di kampung Kota Kapur (Tim Penelitian Arkeologi Palembang, 1992: 264).

Prasasti Kota Kapur adalah Prasasti Sriwijaya yang pertama kali ditemukan, jauh sebelum prasasti Kedukan Bukit ditemukan pada 29 November 1920 dan beberapa hari sebelumnya telah ditemukan Prasasti Talang Tuo pada 17 November 1920, orang yang pertama kali membaca prasasti ini adalah $\mathrm{H}$. Kern, seorang arkeolog bangsa Belanda yang bekerja pada Bataviasch Genootschap di Batavia. Pada mulanya ia menganggap Sriwijaya itu adalah seorang raja (Tim Penelitian Arkeologi Palembang, 1992: 270). Pada 686 M, terdapat refrensi dalam Prasasti Kota Kapur Bangka tentang para pemberontak Jawa yang tidak mau tunduk. Ini berarti pengaruh Sriwijaya paling awal dan pemaklukan Melayu merupakan tahapan dalam persaingan untuk menguasai pantai menjadi tumpuan perdagangan (Woltes, 2011: 294).

Lima tahun setelah penafsiran Kern, barulah diperoleh titik terang soal kata Sriwijaya. G Coedes secara gemilang berhasil mengidentifikasikan Sriwijaya sebagai kerajaan dalam bentuk kedatuan (kumpulan para datu). Kerajaan tersebut pernah disebut dalam kronik-kronik Tiongkok atau perjalanan musafir Tiongkok dan Arab, disinilah Coedes membantah Kern. Menurut Coedes, di depan kata Sriwijaya pada Prasasti Kota Kapur terdapat beberapa seperti kedatuan (kerajaan), datu (raja), atau walla (tentara). Prasasti Ligor atau Vat Semamuang yang ditemukan di Nakhon Si Thammarat di selatan Thailand pun menyebutkan Sriwijaya sebagai kerajaan. Disitu tertulis kata Sriwijayandraja yang berarti raja Sriwijaya. Sementara dalam sebuah prasasti yang dikeluarkan raja India, Raja I tahuhn 1006 Masehi dikenal dengan sebutan Piagam Leiden dengan nama "Marawijayatunggawarman" sebagai raja Sriwijaya dan Kataha (Kedah) (I Made, 2017: 8)

Kemudian atas jasa Coedes, mulailah diketahui bahwa Sumatera abad ke-7 Masehi ada sebuah kerajaan besar bernama Sriwijaya. Sebuah kerajaan yang cukup kuat menguasai barat Nusantara, Semenajung Malaka dan Thailand bagian Selatan (Tim Penelitian Arkeologi Palembang, 1992: 270). Sama seperti Selat Malaka, Selat Bangka juga merupakan salah satu jalur pelayaran dan perdagangan yang ramai dilalui oleh para pedagang dari Arab, Cina, dan India. Para pelayar dan pedagang tersebut keluar-masuk ke 
daerah Nusantara melalui jalur Selat Malaka maupun Selat Bangka.

Jalur pelayaran yang terlihat ramai dan strategis di selat Bangka itulah alasan Sriwijaya untuk mengutamakan penguasaanya, disamping wilayah perairan tersebut memang dekat dengan pusat Kerajaan Sriwijaya di Palembang. Dengan dikuasainya wilayah-wilayah disekitarnya termasuk Pulau Bangka, Sriwijaya seoenuhnya dapat menguasai lalu lintas perdagangan dan pelayaran dari Arab, India dan Cina dan sebaliknya, karena perahu-perahu asing semuanya mau tidak mau harus berlayar melalui Selat Malaka ysng dikuasai oleh Sriwijaya (Sholeh, 2015: 29)

Kekuatan Sriwijaya yang besar telah mampu menguasai daerah perairan Bangka dan sekitarnya, para tentara Sriwijaya membuat pos-pos penjagaan dan keamanan di wilayah tersebut. Penguasaan ada Bangka sudah ada perencanaan penempatan bagi Raja Sriwijaya demi menjamin kekuasaan, keamanan dan serangan musuh dari luar. Maka wajar apabila dalam perluasaannya pertama kali di Pulau Bangka harus ditaklukan pertama kali demi menjamin keaman dan strategisnya pusat Kerajaan Sriwijaya (Sholeh, 2015: 54)

\section{Peranan Sriwijaya dalam Jalur Pelayaran Perdagangan Kuno di Selat Bangka Abad VII - VIII M}

Perdagangan dengan menggunakan jalur air mulai timbul dengan dikenalnya transportasi air. Dalam perkembanganya perdagangan melalui jalur air tidak dapat dipisahkan dengan pelayaran dan perdagangan sehingga menjadi satu kesatuan. Dalam sejarah pelayaran dan perdagangan internasional, kawasan perairan Asia Tenggara dengan Selat Malakanya merupakan salah satu perairan tersibuk yang banyak dilalui pelayar dan pedagang di Asia Tenggara. Kontak awal yang terjadi pada millenium pertama Masehi berkaitan dengan kegiatan perdagangan maritim seperti jalur Selat Malaka maupun Selat Bangka (Wiyana, 2014: 78).Penaklukan Pulau Bangka diduga erat hubungannya dengan penguasa perdagangan dan pelayaran internasional di Selat Malaka.

Kerajaan Sriwijaya merupakan kekuatan pertama dalam sejarah Nusantara berhasil mendominasi wilayah Selat yang memegang kunci perdagangan dan pelayaran baik kenegeri Cina maupun negeri lainnya, seperti ekspansi yang telah dilakukan Sriwijaya ke arah Utara. Ekspansi Tersebut dilakukan untuk mengusai jalur-jalur pelayaran yang strategis seperti Selat Malaka wilayah Kedah, Selat Bangka dan Samudera Hindia (Sholeh, 2015: 64)Selat Bangka merupakan pintu utama masuk pertama kali ke pusat Kerajaan Sriwijaya. Selat Bangka yang sudah diketahui pada abad ke-7 Masehi merupakan Selat yang sangat ramai sekali dikunjungi oleh para pedagang atau pelayaran yang sedang melakukan perjalanan jauh atau sekedar untuk berdagang atau pulau atau antar negara karena Selat Bangka jalur yang harus dilalui oleh para pedagang dari Cina ke India dan Arab atau sebaliknya.

Jalur pelayaran perdagangan dimulai dari Barat sampai Timur Nusantara yang dilanjutkan ke arah Utara yaitu wilayah Asia Timur yang menghubungkan perdagangan dari Arab, India menuju Cina yang melalui Nusantara yang sudah dikuasai Sriwijaya. Jalur-jalur pelayaran memang memiliki daya tarik yang memikat karena letaknya strategis dan dianggap efektif untuk dilakukan pelayaran tujuan yang dimaksud. Kondisi jalur- 
jalur pelayaran dianggap efektif dan nyaman (Sholeh, 2015: 92).Sebagai akibat perdagangan dan pelayaran sejumlah pelabuhan telah tumbuh disepanjang jalan maritim dari Barat ke Timur Nusantrara, dan juga Sriwijaya dalam menjaga kepentingan perdagangannya maka ia melakukan kerjasama dengan mengakui kedaulatan Cina sebagai kekuasaan yag besar dan ditambah lagi Sriwijaya sering mengirim sebuah upeti bagi dinasti Cina demi menjaga kepentinganya di laut dan maupun selat (Marwati, 1990, 77).

Perkembangan kekuasaan Sriwijaya semakin lama semakin luas kekuasaaanya mencapai wilayahwilayah jalur pelayaran dan perdagangan terutama wilayah yang dianggap strategis, khusunya apabila pelayaran harus dilakukan di laut bebas jauh dari daratan (Styawari,1978: 96). Sebagai kekuasaan maritim Sriwijaya yang strategis bagi jalur pelayaran mulai dari Selat Bangka (Sholeh, 2015: 90) Beberapa faktor yang memudahkan Sriwijaya dapat menguasai lautan diantaranya adalah secara geografis pusat Kerajaan Sriwijaya terletak di tepi sungai yang besar, dengan kondisi yang demikian Sriwijaya dapat menggunakan wilayah yang strategis menjadi sebuah jalan untuk memperoleh penguasaan laut.

Untuk menjaga kekuasaan dan keamanan wilayah kepulauan Nusantara, Sriwijaya mengasah dan melatih kemampuan armada-armada tentaranya untuk mengarungi lautan sebagai dasar untuk bertahan dalam pelayaran di laut lepas guna mengamankan wilayah kekuasaanya. Sebagai pelaut andalan Sriwijaya tidak hanya dikenal masa I-tsing, tetapi kepandaian mereka pada abad ke-7 Masehi diraih melalui pertualangan gagah berani dalam menembus
Samudera yang panjang. Bukti kepandaian dalam pelayaran pada masa lalu telah dibuktikan armada-armada Sriwijaya yang telah menguasai seluruh lautan dan selat-selat atau pelabuhan di Nusantara (Sholeh, 2015: 72)

Dengan menonjolkan kekuatan lautnya di Selat Malaka, raja Sriwijaya awal telah berjaya mengatasi tantangan dari para pendatang baru dalam perdagangan ke Cina. Sebagai kerajaan maritim yang berkuasa di laut, kekayaanya diperoleh dari perdagangan internasional melalui Selat Malaka maupun Selat Bangka, yang berarti berhubungan dengan jalur pelayaran dan perdagangan internasional dari Arab, India, Nusantara dan Cina yang telah berabad-abad lamanya mempunyai arti yang penting dalam pelayaran di Nusantara. Itulah sebabnya Sriwijaya menjadi pusat perdagangan yang memiliki peranan penting pada jalan raya lalu lintas perdagangan internasional di Nusantara, pentingnya penguasa Sriwijaya dalam menjaga kekuasaannya di jalur-jalur perdagangan internasional tersebut adalah masalah hubungan pusat Sriwijaya dengan masyarakat pantai daerah bawahan dan masalah hubungan penguasa Sriwijaya dengan negaranegara besar lainnya.

Jalur perdagangan dilalui pada Selat Bangka banyak juga para pelaut yang mempunyai tujuan tidak baik seperti ingin merampok, perampokan atau bajak laut yang ditakuti oleh para pedagangan yang sedang berdagang dengan Sriwijaya. Para perampok banyak menyebar kemana-mana mulai dari pintu masuk Selat Malaka sepanjang pelabuhan-pelabuhan milik Sriwijaya, Selat Bangka dan perairan lainnya.

Dalam menghadapi hal tersebut Sriwijaya memantapkan kekuasaanya di 
jalur perdagangan pelayaran yang strategis dengan memperkuat armadaarmada lautnya dengan pelatihan khusus, adapun pelatihanya mengutamakan ketangguhan dan kecakapan dunia kebaharian untuk menangkap para perampok atau para bajak laut yang terkenal kejam dan ditakuti para pedagang. Perampokperampok di laut terutama jalur pelayaran dan perdagangan di pintu Selat Malaka sampai Selat Bangka pada saat Sriwijaya belum bisa mengedalikan wilayah jalur tersebut maka kondisinya sangat mengkhawatirkan karena masih banyak perampok-perampok merampas barang dagangan dan tidak jarang perampok tersebut membunuh (Sholeh, 2015: 74-76).

Para perompak tersebut banyak mengambil hasil jarahan dari para pedagang. Melihat peluang yang ada di Selat Bangka, penguasa Kerajaan Sriwijaya pada saat itu mengadakan perundingan dengan para perompak yang menguasai Selat Bangka. Raja Sriwijaya mengajakan kerjasama dalam bidang keamanan. Para perompak tersebut diperintahkan untuk menjaga kedamaian dan keamanan diwilayah Selat Bangka. Supaya para pedagang tidak merasa terancam saat memasuki daerah Sumatera. Dengan mengajak kerjasama dengan para perompak dalam bidang keamanan, secara tidak langsung Kerajaan Sriwijaya sudah menguasai Selat Bangka. Selanjutnya Kerajaan Sriwijaya memperluas daerah kekuasaannya dengan cara menduduki daerah Bangka. Itu diperkuat oleh temuan Prasasti yang berada di Pulau Bangka yaitu Prasasti Kota Kapur. Kekuasaan Sriwijaya menekankan pada mereka agar kapal-kapal menuju Cina diarahkan singgah ke pantai nenjadi tumpuan dan melakukan sebagai besar urusannya di sana. Abad ke 7 aturan tersbut berlaku untuk pelayaran Nusantara tetapi akhirnya semua pelayaran asing juga harus tunduk (Wolters, 2011:294).

\section{Pembahasan}

Abad ke-7 Masehi jalur pelayaran dan perdagangan di wilayah perairan nusantara bagian barat yang paling sering dilayari adalah Selat Malaka, Selat Bangka, Selat Gelasa serta Selat Karimata. Pelayar dan pedagang dari Selat Malaka melewati banyak kapalkapal perniagaan melintas di Selat Bangka dalam perjalanannya singgah di pelabuhan Sriwijaya yang merupakan jalur ramai sejak lalu (Novita, 2013: 4748) Pulau Bangka selain tempatnya strategis bagi pelayaran dan perdagangan pada masa kuno tetapi Selat Bangka juga dapat dijadikan benteng pertahanan paling utama dan paling terluas apabila dilihat dari arah laut yang berhadapan langsung dengan Sungai di Palembang.

Letak selat Malaka mengundang perdagangan di daratan Asia Tenggara untuk meluas ke Selatan, suatu hal yang baru terjadi setelah perdagangan dengan India berkembang, penduduk Sumatera khususnya di pantai Timur, bukan asing lagi dalam mengenal perdagangan Internasional. Jalur perdagangan yang dikuasai kerajaan Sriwijaya semakin ramai dan penting disebabkan kerajaan Sriwijaya mampu menjaga keamanan, di samping letak geografisnya yang menguntungkan. Selain jalan dagang lewat lautan luas, para pedagang Arab, Cina, Persia dan India. Pulau Bangka sudah dikenal pada masa kuno sebagai kepulauan yang letaknya di wilayah pantai Timur Sumatera yang sekaligus wilayah yang menempati letak strategis bagi pelayaran, karena di Bangka sendiri terdapat sebuah Selat atau laut sempit 
yang diapit antara daratan Suamatera dengan Pulau Bangka yang disebut Selat Bangka.

Menurut Teori Sukmono, para pedagang harus memutar wilayah Bangka terlebih dahulu karena kondisi secara geografis pulau-pulau atau daratan yang ada di wilayah pantai sebelah Timur Sumatera yang masih dalam kondisi menyatu mulai dari Kepulauan Riau-Lingga sampai ke Bangka. Faktor lain yang membuat Kerajaan Sriwijaya menjadi kekuasaan di laut sehingga disebut kerajaan maritim terbesar pada masa itu adalah faktor kekuatan tentara yang kuat serta manajemen seorang pemimpin yang tegas dan bijaksana dalam mengendalikan jalur-jalur pelayaran perdagangan yang ada di Nusantara.

Bagi Sriwijaya wilayah perairan Pulau Bangka sangat penting untuk dijadikan wilayah kekuasaannya, terbukti pada tahun 686 sesuai tahun dalam prasasti Kota Kapur. Dengan demikian raja Sriwijaya memang benarbenar menginginkan wilayah Bangka terutama daerah peraiaran Bangka untuk dijadikan wilayah kekuasaannya. Sriwijaya melakukan hal tersebut bukan hanya semata-mata ingin menjadi penguasa saja, tetapi melakukan politik perluasan dengan strategi penguasaan wilayah jalur-jalur pelayaran perdagangan yang harus dikendalikan oleh Sriwijaya. Dengan memanfaatkan kondisi perairan Selat Bangka yang ramai dan sekaligus ramai pula akan perompak-perompaknya, maka Sriwijaya datang menjadi penguasa wilayah tersebut.

Menguasai Pulau Bangka, Sriwijaya berangapan selain pentingnya perairan di Pulau Bangka yang harus ditakhlukan pertama kali, oleh karena itu Pulau Bangka merupakan wilayah sangat strategis sebagai pintu utama untuk memasuki pusat Kerajaan Sriwijaya dan setidaknya mau tidak mau wilayah di perairan Selat Bangka harus dikuasai dan menjadi daerah kekuasaanya, Dengan pengaruh Sriwijaya di Selat, era baru pun dimulai dalam sejarah erdagangan Nusantara zaman dulu.

Dalam penaklukan Sriwijaya melewati Selat Bangka terdapat juga hubungan dengan keduanya di provinsi Bangka yaitu peninggalan Sriwijaya pada prasasti Kota Kapur, yang berangka 686 M. Prasasti ini ditemukan tahun 1892 di lahan yang dikelilingi benteng tanah di tepi Sungai Mendo, desa Kota Kapur. Isinya berupa ancaman atau kutukan yang biasa disebut prasasti persumpahan menjelaskan bagi siapa saja yang tidak tunduk kepada raja Sriwijaya akan di bumi anguskan dan dijelaskan pada Prasasti terdapat kalimat penaklukan "Bumi Jawa" yang artinya penaklukan tersebut dasar keinginan membuka jalur dalam memudahkan masuk menyebrangi wilayah Tanah Jawa untuk mengusai Selat Sunda.

Jalur pelayaran yang terlihat ramai dan strategis di selat Bangka itulah alasan Sriwijaya untuk mengutamakan penguasaanya, disamping wilayah perairan tersebut memang dekat dengan pusat Kerajaan Sriwijaya di Palembang. Dengan dikuasainya wilayah-wilayah disekitarnya termasuk Pulau Bangka, Sriwijaya sepenuhnya dapat menguasai lalu lintas perdagangan dan pelayaran dari Arab, India dan Cina dan sebaliknya, karena perahu-perahu asing semuanya mau tidak mau harus berlayar melalui Selat Malaka ysng dikuasai oleh Sriwijaya.

Kekuatan Sriwijaya yang besar telah mampu menguasai daerah perairan Bangka dan sekitarnya, para tentara Sriwijaya membuat pos-pos penjagaan 
dan keamanan di wilayah tersebut. Penguasaan ada Bangka sudah ada perencanaan penempatan bagi Raja Sriwijaya demi menjamin kekuasaan, keamanan dan serangan musuh dari luar. Maka wajar apabila dalam perluasaannya pertama kali di Pulau Bangka harus ditaklukan pertama kali demi menjamin keaman dan strategisnya pusat Kerajaan Sriwijaya (Sholeh, 2015: 54).

Kerajaan Sriwijaya merupakan kekuatan pertama dalam sejarah Nusantara berhasil mendominasi wilayah Selat yang memegang kunci perdagangan dan pelayaran baik kenegeri Cina maupun negeri lainnya, seperti ekspansi yang telah dilakukan Sriwijaya ke arah Utara. Ekspansi Tersebut dilakukan untuk mengusai jalur-jalur pelayaran yang strategis seperti Selat Malaka wilayah Kedah, Selat Bangka dan Samudera Hindia (Sholeh, 2015: 64)

Selat Bangka merupakan pintu utama masuk pertama kali ke pusat Kerajaan Sriwijaya. Selat Bangka yang sudah diketahui pada abad ke-7 Masehi merupakan Selat yang sangat ramai sekali dikunjungi oleh para pedagang atau pelayaran yang sedang melakukan perjalanan jauh atau sekedar untuk berdagang atau pulau atau antar negara karena Selat Bangka jalur yang harus dilalui oleh para pedagang dari Cina ke India dan Arab atau sebaliknya.

\section{Kesimpulan}

Jalur pelayaran perdagangan kuno yang dilewati oleh para pedagang asing masa Sriwijaya seperti dari Arab, Persia, India dan Cina, semuanya melalui jalur pelayaran perdagangan milik kekuasaan Sriwijaya yang ada di Nusantara. Letak starategis jalur pelayaran perdagangan kuno di Nusantara di mulai dari jalur selat Malaka - kepulauan Riau-Lingga - selat Bangka - Karimata dan selat lainnya. Khusus pada selat Bangka memilki letak kestrategisan tersendiri terutama bagi para pedagang asing yang melewati jalur tersebut karena letak selat Bangka yang tepat pada jalur masuk di pusat kerajaan Sriwijaya.

Selat Bangka merupakan jalur pelayaran perdagangan kuno yang secara tidak langsung memberikan keuntungan politik bagi perkembangan kekuasaan maritim Sriwijaya. Bagi Sriwijaya menguasai selat Bangka adalah hal yang paling utama dan penting, terbukti penakhlukkan wilayah Bangka adalah hal yang pertama dilakukan oleh Sriwijaya terutama khusus wilayah di luar Palembang.

\section{Daftar Referensi}

Geria, I Made. 2017. Rumah Peradaban

Kedatuan Sriwijaya Perjalanan Suci.

Jakarta: kemdikbud Bada

Penelitian

dan Pengembangan Pusat Penelitian Arkeologi Nasional.

Irfan, Nia Kurnia Sholihat.1983. Kerajaan Sriwijaya. Jakarta: Girimukti Pasaka.

Kartiwa, Suwati. 2009. Kain Cual Bangka. Jakarta: Direktur Jenderal Kebudayaan.

Novita, Aryandini. 2013. Indentifikasi

Kapal dari Situs Karangkijan

Kabupaten Belitung. (Jurnal

Siddhayatra, Vol. 18 No 1. Mei 2013)

Balai Arkeologi.

Poesponegoro, Marwati Djoened, Nugroho Notosusonto. 1990.Sejarah Nasional Indonesia II. Jakarta: Balai Pustaka. 
Sholeh, Kabib. 2015. Kemaritiman Sriwijaya dan Perdagangan Muslim Palembang abad VII-IX Masehi. Palembang: Noer Fikri.

Sholeh, Kabib, 2017. Jalur Pelayaran dan Perdagangan Sriwijaya pada abad ke-7 Masehi. (Jurnal Sidhayatra, Vol. 22 No. 2. November 2017) Balai Arkeologi Sumatera Selatan.

Sholeh, Kabib, 2018. Pelayaran Perdagangan Sriwijaya dan Hubungan dengan Negeri-negeri luar abad VII-IX Masehi. (Jurnal Historia, Vol. 6 No. 2. Agustus 2018) Univ. Muhamadiyyah Metro.

Styawari. 1978.Pra Seminar Penelitian

Sriwijaya. Jakarta: PT Rora Karya.

Suryana. 2010. Metodologi Penelitian Model Praktis Penelitian Kuantitatif dan Kualitatif. Bandung: Universitas Pendidikan Indonesia.

Syamsudin, Helius. 1996. Metodologi Sejarah. Jakarta: Jalan Pintu Satu, Direktorat Jenderal Dikti Depdikbud.

Tim Penelitian Arkeologi Palembang. 1992.Himpunan Hasil Penelitian Arkeologi di Palembang tahun 19841992. Jakarta: Pusat Penelitian Arkeologi Nasional Depdikbud.

Wiyana, Budi. 2013. Peran Sungai Buding pada Jalur Perdagangan Masa Lalu. (Jurnal Sidhayatra, Vol. 18 No. 2. November 2013) Balai Arkeologi Palembang.

Wiyana, Budi. 2014. Hubungan Perdagangan antara Pantai Timur Sumatera Selatan. (Jurnal Sidhayatra, Vol. 19 No. 2. November 2014) Balai Arkeologi Palembang.
Woltes, O, W. 2011. Kemaharajaan Maritim Sriwijaya dan Perniagaan Dunia Abad III - Abad VII. Jakarta: Komunitas Bambu. 